\title{
Neutrality, fairness or freedom? Principles for platform regulation
}

\author{
Friso Bostoen \\ Institute for Consumer, Competition and Market, KU Leuven, Belgium
}

Published on 30 Mar 2018 | DOI: 10.14763/2018.1.785

\begin{abstract}
The need for online platform regulation has been a topic of scholarly debate. However, reality is now catching up to and even overtaking the academic writing on this subject. France has adopted a law on platform fairness, the European Commission recently ordered Google to implement a form of search neutrality, and more regulatory initiatives are on the horizon. That is why we have to look beyond the question whether online platforms should be regulated. As actual regulation supplants the scholarly debate, we must also examine how they are being regulated. This article distils from the various proposals at EU and member state level a set of operational principles that can serve as a frame of reference for productive debate on platform regulation.
\end{abstract}

Keywords: Platforms, Regulation, Fairness, Neutrality, Transparency, Non-discrimination

\section{Article information}

Received: 27 Sep 2017 Published: 30 Mar 2018

Licence: Creative Commons Attribution 3.0 Germany

Competing interests: The author has declared that no competing interests exist that have influenced the text.

URL:

http://policyreview.info/articles/analysis/neutrality-fairness-or-freedom-principles-platform-regulation

Citation: Bostoen, F. (2018). Neutrality, fairness or freedom? Principles for platform regulation. Internet Policy Review, 7(1). https://doi.org/10.14763/2018.1.785

Acknowledgements: The author wishes to express his gratitude to the Jindal Initiative on Research in IP and Competition (JIRICO) at O.P. Jindal Global University, India, for organising the JIRICO Global Writing Workshop \& Research Colloquium. This paper benefited from the insightful comments of the workshop participants, and-at a later stage-those of the reviewers and editors of Internet Policy Review. Any mistakes are the author's sole responsibility. Finally, the author notes that this paper builds on thoughts presented in the concluding section of a previous article, namely Friso Bostoen (2018). Online Platforms and Vertical Integration: The Return of Margin Squeeze? Journal of Antitrust Enforcement, 6 (forthcoming). 


\section{INTRODUCTION}

The question whether online platforms need to be regulated has been heavily debated by legal scholars without clear answer. However, it appears that policymakers in different EU member states and at EU level have drawn their conclusions and are proposing or adopting regulation. 'Regulation' is used in a broad sense here, referring to specific legal instruments as well as the application of competition law, but this article focuses on the former. Most notably, France has adopted a law on platform fairness, while the European Commission ('Commission') not only ordered Google to implement a form of search neutrality but is also tabling regulatory proposals on fairness in platform-supplier relations.

There is, however, a disconnect between the academic debate and the political reality. The first issue is that legal scholars often discuss the (in)appropriateness of platform-specific regulation without a clear view of what this regulation looks like, which means that both support and criticism miss a clear target. As the scholarly discussion is not centred on the regulation that is actually being proposed, policymakers cannot fully benefit from the academic debate. This brings us to the second issue, namely that policymakers make scholarly discussion difficult by presenting their regulatory proposals in terms of 'fairness' and 'neutrality'-goals that are lofty but meaningless in and of themselves. To solve the two-way disconnect between academia and policy, this article seeks to propose a frame of reference for productive debate on platform regulation. It does so by extracting from the various regulatory initiatives two operational principles, namely transparency and non-discrimination.

To achieve its goal of presenting meaningful principles for platform regulation, the article is structured in three parts, each with its proper methodology. It starts with a brief doctrinal review of the legal debate on the need for platform regulation (section 2). While platforms give rise to several concerns, the article identifies the economic dynamic that is at the heart of many of the regulatory initiatives (section 3). The main resource for this exercise is the economic literature on online platforms, which is primarily theoretical but incipiently empirical. The main part of the article then surveys the policy initiatives targeting online platforms both at the EU level and at the member state level with a focus on France (section 4). As there is a lack of primary research on this topic, an objective preliminary description of the (proposed) legal instruments is crucial. Through a critical analysis, the article then distils from these instruments operational principles for platform regulation, and identifies in which cases they can serve a purpose.

\section{THE NEED FOR ONLINE PLATFORM REGULATION}

Many authors have discussed the need for regulation of online platforms such as Google, Amazon, Facebook and Apple. Their views can be split up in two camps, which may be termed-with some simplification-'anti intervention' on the one hand and 'pro intervention' on the other.

In the anti-intervention camp are authors who argue that intervention in digital markets should be kept to a minimum. The reasons they offer vary. Some argue that competitive issues are unlikely to develop in digital markets (Rato \& Petit, 2014, p. 8) and that when they do, the dynamic nature of these markets will quickly correct them (Evans, 2017). A related argument 
goes that intervention in these fast-paced digital markets is prone to decisional errors, which would stifle innovation (Shelanski, 2013). Others make the more general argument that regulation should not focus on the phenomenon of platforms, in other words, that there should not be a 'law of the platform' (Lamadrid, 2015; Lobel, 2016). This argument goes back to a speech by Frank Easterbrook, in which he argued that there should not be a 'law of the cyberspace' any more than that there should be a 'law of the horse', but that new phenomena should rather be assessed according to general legal principles that existed before their rise (Easterbrook, 1996). Relatedly, some authors argue that the lack of a clear definition of 'platform' make the creation of a targeted regulatory framework difficult (Maxwell \& Pénard, 2015, pp. 7-11).

In the pro-intervention camp are authors who do believe that there are competitive issues with online platforms that should be addressed. While some authors argue that any issues can perfectly be addressed under the current competition rules, a number of others argue that competition law should be tailored to digital markets in order to fully solve the issues at hand. On the one hand, their work includes proposals for substantive reform-i.e. changing the law itself, or at least its interpretation (Khan, 2017, pp. 790-797). On the other, they offer suggestions for procedural reform-i.e. changing how the law is administered-with a particular focus on the need to speed up interventions to keep pace with the fast-moving digital sector (Kadar, 2015, pp. 19-23). A final group of authors holds the view that the current situation justifies the adoption of a new regulatory framework that would apply to (certain) online platforms. The argument goes that some (especially data-related) issues are simply not sufficiently addressed by any branch of the current legal framework (Strowel \& Vergote, 2016, pp. 11-15).

The merits of each position can be elaborately discussed. On the intervention side, a lot of work on the application of general competition law to online platforms remains to be done. However, some EU member states have either skipped this exercise or drawn their conclusions and moved to the next stage by adopting more specific regulation targeting online platforms. Before discussing the regulatory initiatives themselves, let us take a look at the (anti-)competitive dynamic of online platforms that authorities are increasingly regulating.

\section{THE SUBJECT OF ONLINE PLATFORM REGULATION}

The preliminary question is how to define an online platform. However, agreement on such a definition is elusive. Generally, they can be described as intermediaries operating in multi-sided markets, in which they seek to facilitate direct interaction between different user groups-the 'sides' of the market (similarly Rochet \& Tirole, 2003). While it is difficult to describe what platforms are, it is easier-and for the purpose of regulating them more important-to describe what they do. A wealth of online platforms exist, but with a view to making everything 'as simple as possible, but not simpler' (Einstein), it can be said that the core role of platforms consists in search and matching (Martens, 2016, pp. 20-26).

The most obvious kind of matching platforms are online dating/marriage services like the American Match.com and the Indian Matrimony.com. Other platforms, such as Upwork and MTurk, connect persons with a job with an on-demand workforce to carry it out. However, most matching platforms do not seek to facilitate a (working) relationship, but rather a transaction. Mobile app stores (like Apple's App Store and Google Play) serve as a good example: they facilitate transactions between app developers (suppliers) and consumers. These kinds of 
platforms profit by charging suppliers a commission on every transaction. For app stores, for example, this commission amounts to $30 \%$ of the price of the app (and subsequent in-app purchases or subscriptions).1

The focus of other platforms lies more with search than with matching. Search engines such as Google serve as a prime example. Their main function consists in listing and ranking information on the Web. In doing so, they connect not two but three user groups: users seeking information, websites seeking an audience, and advertisers seeking new customers. This intermediation is free for users and websites, and financed by advertisers who generally pay each time a user clicks on the link to their website (a 'pay per click' model).

However, these two core functions do not lead to a strict dichotomy, as many platforms combine elements of both categories. Consider Amazon Marketplace. Shopping on this platform usually starts with a search query, after which Amazon offers a ranking of results. Some of these results will have been paid for by advertisers, others will pop up organically. When consumer and supplier have found each other, Amazon facilitates the transaction between them. Thus, Amazon Marketplace intermediates between consumers, advertisers and suppliers. Price comparison websites (such as Booking.com for hotels) function in a similar way.

Platforms and suppliers are in what has been called a 'frenemy relationship' (Ezrachi \& Stucke, 2016, pp. 147-158). In a first period, platforms need suppliers: as platforms only offer a digital infrastructure for interaction, a platform without suppliers is simply worthless to consumers; intermediation only works with two user groups to connect. In a second period, when a platform becomes larger, its suppliers become more dependent on it to provide their services to consumers (European Commission, 2016a, p. 13). In that situation, the platform may seek to capture more of the value in the supply chain. A first, straightforward way to do so is by increasing the commission rate/pay per click fee it demands from suppliers.

There is also a more intricate-and possibly more profitable-way to capture more value, namely by integrating vertically. Vertical integration means that the platform starts creating its own goods or services for distribution through its platform, in order to make an additional profit on those sales. After such vertical integration, the platform actually competes with certain suppliers, which creates an incentive to exclude them. This exclusion can be carried out explicitly through the delisting of certain suppliers from the platform (e.g. Dredge, 2013). More often, however, this exclusion proceeds through a subtle combination of commission rates imposed on the supplier and the ranking of results presented to the consumer. In both cases, the platform operator uses its control over the ecosystem to favour its own goods and services.

We have seen this dynamic play out before. Apple, for example, integrated vertically when it started offering Apple Music, a music streaming app, through its own App Store. It subsequently sought to make subscribing to Spotify, a competing app, less attractive through a combination of high commission rates and restrictive conditions (Crook, 2016). Google's search engine used to direct consumers to more specific services. Now that Google has its own specialised services (e.g. comparison shopping and flights), consumers are pointed in that direction (Google Search, 2017; Google India, 2017). Amazon Marketplace, finally, does not only connect sellers to buyers, but also operates as a seller itself. When Amazon starts producing a new good, it skews its algorithms in favour of this offering (Angwin \& Mattu, 2016).

A public consultation carried out by the European Commission shows this sort of behaviour is perceived as a wider problem: $90 \%$ of responding businesses (out of a total of 116) replied that they are dissatisfied with the relations between platforms and suppliers. The problematic 
practices most commonly experienced by these businesses were: (i) a platform applying unbalanced terms and conditions; (ii) a platform promoting its own services to the disadvantage of services provided by suppliers; and (iii) a platform refusing access to its services (European Commission, 2016b, p. 9).

Because of their exclusionary nature, these practices merit our attention. After all, consumers may suffer the consequences: empirical case studies indicate that unfair platform-supplier competition can reduce innovation and increase prices (Wen \& Zhu, 2017), limit consumer choice (Zhu \& Liu, 2016), and degrade the quality of the platform (Luca et al., 2016). The first regulatory reflex in this case should be competition law. However, given the novelty of this issue (and the duration of proceedings), competition law has not been sufficiently applied to potentially abusive behaviour in the digital economy, and it thus remains unclear whether this branch of law can adequately regulate online platforms. Nevertheless, some authorities in Europe have (at least implicitly) concluded that competition law is not up to the task. Consequently, they are preparing or have already adopted specific regulation targeting the relationship between platforms and suppliers, which is the subject of the next section.

\section{THE PRINCIPLES OF ONLINE PLATFORM REGULATION}

\subsection{INTRODUCTION}

The possibilities for platform regulation are situated on a broad spectrum limited by two extremes. On one side of this spectrum, we find the complete freedom from regulatory intervention for platform operators. While such freedom is difficult to imagine, since platforms are subject to various parts of the current legal framework, eleven EU member states did call on the Commission not to specifically regulate platforms (Joint letter, 2016). Situated on the other side of the spectrum are complete bans on certain platform behaviour. We are now seeing an example of the latter in the bans on so-called 'most favoured nation clauses' between booking platforms and hotels. These clauses prohibit the hotel from offering their rooms at a lower price or under better conditions on their own website and/or on other platforms. After competition authorities took a balanced approach regarding the permissibility of these clauses, legislators in several member states outright banned them (Bostoen, 2017b).

Between leaving platforms complete freedom and completely banning some of their behaviour are a number of options that authorities in Europe are exploring. Most of the regulatory initiatives are centred around two principles, namely neutrality and fairness. Of course, these principles do not mean much in and of themselves; it is their content that matters. This section will examine the different regulatory initiatives, organising them by the principle they claim to represent, but with specific regard for their content.

\subsection{NEUTRALITY}

The first principle that surfaces in (or lies under the surface of) a number of regulatory initiatives is neutrality. This principle is not new, but has often been included in instruments regulating network sectors. In telecommunications regulation, we have two precedents that are especially relevant, both of which impose a form of network neutrality through an obligation of non-discrimination. 


\section{a. Network neutrality}

Starting in the 1990s, the European telecom sector was liberalised under direction of the Commission (Directive 2002/77/EC). Member states were obliged to abolish exclusive or special rights for the provision of telecom services (which were often provided by former state monopolies) and the telecom network was opened up to entrants who could compete with the incumbent in providing those services. In this situation, the incumbent would regularly end up both providing network access to entrants (upstream market) and competing with them in offering services to end-users (downstream market). To ensure effective competition, a certain neutrality was imposed on the provider of the network:

Member States, shall ensure that vertically integrated public undertakings which provide electronic communications networks and which are in a dominant position do not discriminate in favour of their own activities.

For example, the incumbent could engage in such discrimination by charging higher prices for network access to downstream competitors than to its own downstream operations. If this price charged to competitors for access to the incumbent's network was too high, or the price charged by the incumbent to end-users too low, then entrants could not effectively compete on that downstream market. In that case, the Commission would intervene through competition law enforcement, more specifically with the figure 'margin squeeze' (Bostoen, 2017a).

Margin squeeze is defined as the situation where a dominant undertaking charges 'a price for the product on the upstream market which, compared to the price it charges on the downstream market, does not allow even an equally efficient competitor to trade profitably in the downstream market on a lasting basis' (European Commission, 2009, para. 80). In other words, margin squeeze targets the situation where a network operator forces his downstream competitor-who is just as efficient-off the market by squeezing his profit margins.

In a next step, neutrality obligations were expanded from the telecom network itself to the internet services provided through this network. Net neutrality, a term coined by Tim Wu in 2003, implies that internet service providers ('ISPs') must treat data equally, i.e. cannot block or slow down specific applications or services. In April 2016, the EU Regulation on net neutrality came into force, aiming 'to safeguard equal and non-discriminatory treatment of traffic in the provision of internet access services' (Regulation (EU) 2015/2120, consideration 1).

The new Regulation is motivated in part by worries concerning vertical integration, the idea being that ISPs could give their downstream services preferential treatment over those of competing content providers. They could, for example, slow down Youtube and Netflix to make their video service more attractive, make Spotify's traffic shaky to draw users to its own music streaming service, or mess with the speed of online communication services to make their own apps more popular. Such conduct is prohibited by Article 3 of the Regulation, which states:

\section{Providers of internet access services shall treat all traffic equally, when providing internet access services, without discrimination, restriction or interference, and irrespective of the sender and receiver, the content accessed or distributed, the applications or services used or provided, or the terminal equipment used.}

Thus, the EU mandates neutrality in providing access to the telecom network, and in treating 
services on the internet. There are two important parallels between these neutrality policies. Firstly, they seek to prevent networks from excluding undertakings that use their network, i.e. downstream telecom entrants in the case of margin squeeze and content providers in the case of net neutrality. Secondly, they are implicitly premised on the idea that these networks are essential enough to be qualified as 'utilities'. In the US, for example, net neutrality was imposed by classifying ISPs as 'common carriers', which meant they had to comply with the same nondiscrimination obligations as railways and telephone companies (Open Internet Order, 2015).

Given the importance of online platforms for a great number of businesses, and the fact that vertical integration leads them to exclude competitors from their network, one may wonder whether they should be the next target of neutrality obligations. US Senator Al Franken supports such a move, stating in a recent speech: 'As tech giants become a new kind of internet gatekeeper, I believe the same basic principles of net neutrality should apply here' (Franken, 2017).

However, some authors have argued that the analogy between ISPs and online platforms-or between network and platform neutrality-is not justified (Renda, 2015; Ammori, 2016). For one, the goals of net neutrality do not only include competition but also broader objectives such as media pluralism and freedom of expression. The most convincing distinction is that telecom networks, contrary to online platforms, are natural monopolies (additionally, they often started as public undertakings, at least in Europe). A related argument goes that, while users of online platforms can easily multi-home (i.e. shift between different providers), high switching costs confine users to one ISP. Despite these arguments, we are now seeing neutrality obligations in the platform economy.

\section{b. Platform neutrality}

After seven years of investigation, the Commission issued its decision in the Google Search case in 2017. It decided that Google has abused its market dominance as a search engine by giving an illegal advantage to another Google product, its comparison shopping service. According to the decision, Google systematically gave prominent placement to its own comparison shopping service while demoting rival comparison shopping services in its search results. In other words, Google used its control of the platform (the search engine) to favour its own service (comparison shopping). The imposed remedy is as follows (European Commission, 2017a):

\section{[T] he Decision orders Google to comply with the simple principle of giving equal treatment to rival comparison shopping services and its own service: Google has to apply the same processes and methods to position and display rival comparison shopping services in Google's search results pages as it gives to its own comparison shopping service.}

Thus, the Commission imposed a form of search neutrality, but left the implementation up to Google. The Commission did specify that it 'does not object to the design of Google's generic search algorithms or to demotions as such, nor to the way that Google displays or organises its search results pages (e.g. the display of a box with comparison shopping results displayed prominently in a rich, attractive format)' (European Commission, 2017b).

To comply with the decision, Google has created a stand-alone unit for Google Shopping. Where the coveted top spots on a general Google Search page were previously reserved exclusively for Google Shopping, it now has to bid for those spots against other comparison shopping services 
(Heckman, 2017). According to the company, Google Shopping will participate in the auction the same way as everyone else, and thus compete on equal terms. In essence, Google is instituting a behavioural separation between its search engine and its comparison shopping service. However, this choice of remedy has not escaped criticism: in February 2018, a number of complainants addressed a letter to the Commission arguing that "without full ownership unbundling (structural separation), Google Shopping's participation in the auction is essentially meaningless' (Foundem et al., 2018).

The Google decision was far from the first initiative to regulate the search engine. In 2014, the European Parliament adopted its so-called 'Google Resolution'. Concerned with the evolution of search engines into gatekeepers, it called on the Commission 'to consider proposals aimed at unbundling search engines from other commercial services' (European Parliament, 2014, point 15). Given its general wording, the resolution can be interpreted as recommending anything from a behavioural separation to a structural break-up, but was probably just intended to put pressure on the Commission to swiftly and strongly conclude the Google investigation.

In 2015, the French senate adopted its 'Google Amendment'. The amendment (which did not make it into law) would have imposed a number of obligations on every search engine "with a structuring effect on the digital economy', including (i) making available three other search engines on its home page; (ii) informing its users of its general ranking principles; and (iii) ensuring that search results are fair and non-discriminatory, and do not favour the search engine's specialised services. ARCEP, the French telecom regulator, would be tasked with the enforcement of these obligations.

While the Google Search decision imposes neutrality on one platform within a specific group of platforms (search engines), the French Digital Council drafted a report on platform neutrality (neutralité des plateformes) with a broader scope. The Council describes how, as intermediaries, platforms do not only connect their users but may also become their competitors. They note how this intermediary position gives platforms a big competitive advantage over their suppliers, which may lead to discriminatory and non-transparent conditions of access to the platform. Accordingly, it is crucial that ranked results are fully transparent, so that users can easily distinguish between results paid for by advertisers, results favoured because of their relation with the platform, and general algorithmic results (Conseil National du Numérique, 2014, pp. 8-9, 12, 16).

In an annex to the report, the French Digital Council launches some ideas for platform neutrality (Conseil National du Numérique, 2014, pp. 28-29). These include creating a prohibition of every form of discrimination with respect to suppliers that is not justified by the quality of the service or legitimate economic reasons. Another idea consists in the principle of equal access for suppliers who have become competitors of indispensable platforms, which would particularly apply to rankings and to conditions of access. The report was ordered by and submitted to the French government, and some of its considerations made it into the French law on platform fairness, which is discussed under the next subsection.

\subsection{FAIRNESS}

Apart from neutrality, authorities-most notably in France and at the EU level-have included fairness as a guiding principle in their regulatory initiatives. The most salient example is the law on platform fairness (loyauté des plateformes) adopted by the French Parliament in 2016. The groundwork for this law was laid by the Digital Council's 2014 report on platform neutrality discussed above, but various other reports followed. 
Also in 2014, the French Council of State drafted a report on 'fundamental rights on the internet'. In the report, it observes that marketplaces and search engines no longer play the purely technical and passive role that is required to benefit from the safe harbour regime contained in the E-commerce Directive. The Council thus considers it necessary to create a new legal category for platforms that offer ranking or listing services for content, goods or services placed online by third parties. It argues that these platforms cannot be subjected to a principle of neutrality (or equal treatment), because it is their role to hierarchise results on the internet (thereby favouring some over others). According to the French Council of State, these ranking platforms should be subjected to a principle of fairness towards both consumers and suppliers (Conseil d'Etat, 2014, p. 21). The specific obligations deriving from this principle would have to be defined, and the Council proposes four (Conseil d'Etat, 2014, pp. 278-281):

1. Platforms are not allowed to alter or distort their ranking for purposes contrary to the interests of their users, and should not favour their own services over their competitors';

2. Platforms should inform the users of the general workings of their algorithm, and should clearly distinguish between results paid for by advertisers, results favoured because of their relation with the platform, and general algorithmic results;

3. Platforms should publish their criteria for removing lawful content and apply them in a nondiscriminatory manner;

4. Platforms should communicate in advance with suppliers about any changes in their content policy or the workings of their algorithm that may affect them.

After enshrining the principle of fairness in law, these obligations could either be specified by the platforms in charters of professional conduct, or be adopted by law too. A number of (existing) authorities, including the French competition authority and ARCEP, would be tasked to enforce the obligations. Note that, apart from a different terminology ('fairness' instead of 'neutrality'), the report described shows a lot of commonality with the report on platform neutrality by the French Digital Council (and with the French senate's 'Google Amendment', which came later).

In 2015, the French Digital Council drafted another report, this time titled 'digital ambition'. One chapter is titled 'platform fairness', a visible terminological change from its previous report on platform neutrality (Conseil National du Numérique, 2015, pp. 58-78). It starts out by describing a 'structural imbalance' between the platform and its suppliers due to the intermediary position of the platform, which may-when vertically integrated-also compete with its suppliers. After observing that existing law remains difficult to apply to platform conduct, the Council proposes to adopt a general principle of fairness.

This principle seeks to oblige the platform to carry out its services in good faith without distorting them for purposes contrary to the interests of their users (both private and professional). A clear separation between organic search results, sponsored search results and search results 'internal to the platform ecosystem' would have to be imposed. With a view to normalising access to 'inescapable' platforms, the Council adds two more recommendations: (i) to install an obligation for the platform to inform its suppliers in advance in case of major changes (relating e.g. to tariffs, content or algorithms); and (ii) to apply a principle of nondiscrimination in ranking, except in case of legitimate considerations that are compatible with the interests of internet users.

The scope of application of these obligations would not be determined by a definition, but by a number of criteria (including the platform's audience, its massive adoption and its ability to harm innovation), which would single out platforms 'with the greatest capacity for hindrance'. Enforcement of these obligations would, in the first place, be the task of existing regulatory 
authorities. However, the Council also recommends creating two new institutions: (i) a European fairness rating agency, based on an open network of contributors; and (ii) a body of algorithm experts that can be mobilised on the demand of a regulatory authority.

The last decisive step towards the French law on platform fairness was a 2015 report on 'a new democratic age' by a legislative commission. The report refers to both the work of the French Digital Council and Council of State, and adds critical notes (Commission de réflexion et de propositions sur le droit et les libertés à l'âge numérique, 2015, pp. 197-225). It starts by describing the competitive dynamics of online platforms, and how some of them have grown into 'quasi-inescapable' intermediaries. The report particularly notes how these platforms are able to impose significantly imbalanced conditions on their suppliers, and how-after vertical integration - they are able to restrict competition by favouring their offer over their suppliers'. Moreover, it is not always easy for users to determine when this happens.

In the first place, the report finds it necessary to better adapt competition law to online platforms. It also believes there is room for a specific regulatory instrument beyond competition law, but takes note of several issues. Firstly, there are the definitional problems. In that regard, the report finds the platform definition in the Council of State's 2014 report flawed because it is both too broad (as it targets all platforms, not only those in a dominant position) and too narrow (as it captures only platforms whose content is determined by third parties, not those with a greater editorial role such as Netflix or Spotify). It also takes issue with the Digital Council's focus on platforms with 'the greatest capacity for hindrance' as this is more of a moral than a legal notion. The report prefers the notion of 'digital platforms that are structuring for the economy'. Finally, the report goes into objectives of the regulation, and the different ways to conceive the obligations. It examines different ideas, most of which are centred on transparency and non-discrimination. However, it does not offer any proper suggestions.

After this series of reports, the French parliament adopted a law on platform fairness in October 2016 (Loi n 2016-1321, Article 49). The law applies to 'platform operators', which are defined as every natural or legal person offering professionally-whether remunerated or not-a public online communication service relying on:

1. listing or ranking through data processing the content, goods or services offered or uploaded by third parties; or

2. connecting multiple parties for the sale of a good, the provision of a service, or the exchange or sharing of content, a good or a service.

It is interesting to see that the law opts for a platform definition based on its core functions, namely search and matching. The law obliges the online platform operator to offer the consumer faithful, clear and transparent information, especially regarding:

1. the general terms and conditions of use of the intermediation service, and the methods of listing and ranking and delisting;

2. the existence of a contractual relationship, a capitalistic link or direct remuneration that influences the listing or ranking.

In other words, what the law imposes is transparency. On 29 September 2017, three decrees were adopted to specify these obligations. One decree elaborated on the information obligations, but the most important decree specified the scope of the new law (Décret $n^{\circ}$ 2017-1435): it applies to platforms that receive over five million unique visitors per month-an objective criterion that contrasts with earlier proposals centred on more subjective notions such as 'greatest capacity for hindrance' or 'structuring effect on the digital economy'. 
At EU level, the Commission is monitoring online platforms closely in the framework of its Digital Single Market (DSM) strategy. After the aforementioned public consultation showed widespread dissatisfaction with the platform-supplier relationship, the Commission noted: 'Beyond the application of competition policy, the question arises as to whether EU-level action is needed to address fairness of [...] relations between platforms and their suppliers' (European Commission, 2016a, p. 13). It started by carrying out a fact-finding exercise on platform-tobusiness trading practices.

The Commission presented the results of its fact-finding exercise in the May 2017 mid-term review of its DSM strategy (European Commission, 2017c, pp. 8-9). They indicate that 'some online platforms are engaging in trading practices which are to the potential detriment of their professional users, such as the removal ('delisting') of products or services without due notice or without any effective possibility to contest the platform's decision'. There is also 'widespread concern that some platforms may favour their own products or services [or] otherwise discriminate between different suppliers and sellers'. A final key issue is the lack of transparency in ranking or search results.

All of this led the Commission to conclude that 'platforms have become key gatekeepers of the internet, intermediating access to information, content and online trading.' Accordingly, it pledged to use its competition enforcement powers wherever relevant, and started exploring regulatory options, which it recently specified in an inception impact assessment on 'fairness in platform-to-business relations' (European Commission, 2017d). The options range from 'EU soft law action to spur industry-led intervention' to 'EU legislative instrument providing detailed principles', but are short on specifics. The move enjoys support from the European Parliament, which has called for a 'targeted legislative framework for B2B relations based on the principles of preventing abuse of market power and ensuring that platforms that serve as a gateway to a downstream market do not become gatekeepers' (European Parliament, 2017, pp. 15-6).

\subsection{TRANSPARENCY AND NON-DISCRIMINATION: PRINCIPLES WE CAN (DIS)AGREE ON}

The proposals for platform regulation discussed above brand themselves around 'neutrality' and 'fairness'. While such terms sound lofty, and as we have already stated, they do not carry much meaning in and of themselves. In the preceding section, we therefore took a closer look at how exactly regulatory authorities conceive these principles. This subsection distils from these various conceptions more substantive principles, which can then form the basis of meaningful discussion on their merit.

Most of the initiatives are concerned with the search function of platforms, having Google as their explicit or implicit main target. Generally, the scope of application of these new regulations is defined as online services that list or rank the content, goods or services of third parties, which would also capture marketplaces (such as Amazon's). Such a functional definition circumvents the disagreement on a conceptual platform definition, but focusing solely on the listing/ranking function means that not only intermediaries but also undertakings that operate a more traditional distribution model (e.g. Netflix and Spotify) are included.

Another question is whether regulation should target every online platform, or only those platforms in a dominant position (or with a significant effect on the economy otherwise defined). Dominance assessments-especially in dynamic, two-sided markets-may be difficult, but a general application of the obligations would unduly burden smaller operators. A solution is offered by the French law on platform fairness, which defines its scope of application by 
reference to unique monthly visitors-a measure that is easy to (self-)assess. Other objective measures, such as the amount of active (business) users or employees of the platform, are also conceivable.

Almost all proposals for regulatory intervention are centred around 'neutrality' and 'fairness'. However, the fact that proposals under different names overlap, while proposals under the same heading differ, shows how these terms are impossible to evaluate as such. This article proposes to shift the debate towards two clearer principles, namely 'transparency' and 'nondiscrimination'. Both of these principles serve to establish a more level playing field between platforms and their suppliers, but while transparency only tempers the benefit a platform can derive from favouring its own services over those of certain suppliers, non-discrimination limits or even eliminates this possibility.

\section{a. Transparency}

The primary transparency obligation is making a clear distinction between search results that are generated organically by the search algorithm, the results that are paid for by advertisers, and the results that are favoured because of their connection to the platform. This transparency must be ensured towards consumers. However, when consumers distrust advertised and favoured results, it also has an effect on competition between suppliers and between the platform and suppliers.

A second kind of transparency is geared directly towards suppliers. Suppliers should, in the first place, receive information on the platform's ranking algorithm. Transparency would also comprise the timely communication by the platform of significant changes in its ranking policy or terms and conditions. Rather than general announcements, this information obligation would have to be carried out specifically towards the supplier that is impacted by the change (e.g. a demotion or delisting). Such transparency may, for example, give developers the opportunity to adapt their apps to the changing terms and conditions governing the platform's application programming interface (API), rather than being removed from the platform for non-compliance with unnotified changes. If it does come to a delisting, the platform should provide reasons.

Transparency on the internet enjoys broad support, as illustrated by its inclusion in the OECD Principles for Internet Policy Making (2011, p. 8). The European Council has joined the European Commission and Parliament in stressing 'the necessity of increased transparency in platforms' practices and uses' (2017, p. 5). However, many authorities consider that transparency (alone) will not solve the perceived competitive issues and believe that nondiscrimination is called for. This is also what happened in the course of the Google Search investigation: Google offered to maintain a high degree of transparency-and more (European Commission, 2013), but the Commission did not accept these commitments and finally ordered Google to comply with the principle of equal treatment.

\section{b. Non-discrimination}

Non-discrimination (or its positive equivalent: equal treatment) goes a step further than transparency. It generally implies that an online platform cannot discriminate in favour of its own offering. In the first place, this means that the platform cannot skew the search results in favour of its own services. However, algorithms are meant to favour certain results and demote others to present a useful ranking. Mindful of this inherent function of algorithms, authorities have sought to specify the obligation of non-discrimination. The common formula then goes that platforms cannot alter or distort the ranking 'for purposes contrary to the interests of its users'. However, a more objective measure, i.e. applying 'the same underlying processes and methods' to ranking rival and proper services (Google Search, 2017, para. 700), seems 
preferable.

Search rankings are only one part of many platforms. When it comes to matching different users, high commission rates or restrictive conditions are of concern. In this context, regulatory proposals refer to a right of equal access to the platform for suppliers, especially after the platform integrates vertically. With regard to conditions governing the supply of services through the platform, equal access is easily conceivable. For example, when the app store's own music streaming app is offering a family subscription, the app store must allow other music streaming apps to do so too.

With regard to commission rates, however, equal access is a lot more difficult. When a platform provides services on its own platform, it does not have to pay a commission rate on every transaction. By contrast, the commission rates imposed on suppliers can be substantial, which has led to allegations of anti-competitive conduct. Music streaming apps, for example, have complained that the $30 \%$ cut they owe Apple on subscriptions sold through the App Store makes it difficult to compete against Apple's own streaming service (Singleton, 2015)-conduct that is being investigated by the U.S. Federal Trade Commission (Warren, 2016, pp. 2-3).

Obliging platforms to charge equal commission rates on its own downstream services and on those of competing suppliers is a bad idea: either the commission rate on competing products is scrapped and the platform business model collapses for lack of profits, or the platform charges its downstream services an equal rate, which would have no effect because this constitutes an internal transfer. An idea would be to determine fair, reasonable and non-discriminatory terms for access to the platform, but regulators would then have to engage in the difficult exercise of price regulation. Moreover, such an obligation would be premised on the debatable idea that certain online platforms are essential to suppliers.

A better idea to prevent commission rates from distorting competition on online platforms is applying the margin squeeze test (Bostoen, 2018). Translating this test to the platform economy would mean asking the following question: could the vertically integrated platform offer its downstream product to end-users profitably if it had to pay its own commission rate? Applied to the example above, the question would be: is Apple's music subscription model profitable after discounting the $30 \%$ cut imposed on competitors? If not, the platform would have to adapt either its commission rate or the price of its downstream product. Note that applying this framework does not even require adopting a new non-discrimination rule, as margin squeeze is already part of current competition law.

\section{CONCLUSION}

The relationship between online platforms and suppliers is a difficult one. Firstly, suppliers are often dependent on the platform they use to offer their products to consumers. Additionally, platforms increasingly integrate vertically, which means they start competing with their suppliers on the downstream market. This gives them an incentive to exclude competing suppliers-an incentive that is not infrequently acted upon. Incipient empirical research shows that these practices do not only harm competitors but can also harm consumers. In that case, platform-supplier competition must be regulated.

This article sought to bring clarity to the debate on platform regulation. It did so by delving into the various regulatory initiatives, most of which-at least in name-centre around the concepts 
'fairness' and 'neutrality'. Closer inspection revealed that the obligations they contain can be better described along the lines of 'transparency' and 'non-discrimination'. The final subsection then evaluated these principles and offered suggestions to operationalise them.

While this article has set out a frame of reference for productive debate on platform regulation, it has not settled the debate. Indeed, the question remains whether ex ante regulation is required to address the identified anti-competitive dynamic. The Google Search investigation, for example, has shown that both transparency and non-discrimination can also be imposed ex post through competition law. The choice of ex ante over ex post regulation should be determined primarily by (i) how widespread and harmful anti-competitive conduct in platformsupplier relations is; and (ii) whether competition law (and related legal branches) can provide adequate redress.

Until enough relevant data-i.e. economic research and decisions by competition authorities-are available to make a reasoned choice, it appears prudent to shy away from an $e x$ ante obligation of non-discrimination for online platforms (similarly CERRE, 2017, pp. 58-59). Less restraint should be shown in imposing non-discrimination duties either after establishing a sui generis abuse (as in Google Search) or by applying the margin squeeze framework. A useful first step would be to impose ex ante transparency obligations-which are less intrusive-in order to test their effectiveness.

Most importantly, it is hoped that the principles of transparency and non-discrimination presented here may serve as a focal point for the inevitable future discussions on platform regulation. 


\section{REFERENCES}

Ammori, M. (2016). Failed Analogies: Net Neutrality vs. "Search" and "Platform" Neutrality. In Aitor Ortiz (ed.), Internet Competition and Regulation of Online Platforms (pp. 52-58).

Competition Policy International. Available at

https://www.competitionpolicyinternational.com/wp-content/uploads/2016/o5/internet-comp etition-libro.pdf

Angwin, J. \& Mattu, S. (2016, September 20). Amazon Says It Puts Customers First. But Its Pricing Algorithm Doesn't. ProPublica. Retrieved from

www.propublica.org/article/amazon-says-it-puts-customers-first-but-its-pricing-algorithm-doe snt

Bostoen, F. (2017). Margin Squeeze: Where Competition Law and Sector Regulation Compete. Jura Falconis, 53(1), 3-60. Retrieved from https://papers.ssrn.com/sol3/papers.cfm?abstract_id=2922633

Bostoen, F. (2017). Most Favoured Nation Clauses: Towards an Assessment Framework under EU Competition Law. European Competition and Regulatory Law Review, 1(3), 223-236. doi:10.21552/core/2017/3/9

Bostoen, F. (2018). Online Platforms and Vertical Integration: The Return of Margin Squeeze? Journal of Antitrust Enforcement, 6, forthcoming. Retrieved from https://papers.ssrn.com/sol3/papers.cfm?abstract_id=3075237

Centre on Regulation in Europe. (2017). Internet Platforms and Non-Discrimination. Project Report. Retrieved from http://www.cerre.eu/publications/internet-platforms-non-discrimination

Commission de réflexion et de propositions sur le droit et les libertés à l'âge numérique. (2015). Numérique et libertés: Un nouvel âge démocratique. Report.

Conseil d’Etat. (2014). Le numérique et les droits fondamentaux. Report.

Conseil National du Numérique. (2014). Neutralité des plateformes: Réunir les conditions d’un environnement numérique ouvert et soutenable. Opinion.

Conseil National du Numérique. (2015). Ambition numérique: Pour une politique française et européenne de la transition numérique. Report.

Crook, J. (2016, June 30). Spotify and Apple are staring each other down while flipping the bird. TechCrunch. Retrieved from https://techcrunch.com/2016/o6/30/spotify-and-apple-arestaring-each-other-down-while-flipping-the-bird/

Décret $\mathrm{n}^{\circ}$ 2017-1435 du 29 septembre 2017 relatif à la fixation d'un seuil de connexions à partir duquel les opérateurs de plateformes en ligne élaborent et diffusent des bonnes pratiques pour renforcer la loyauté, la clarté et la transparence des informations transmises aux consommateurs. Available at https://www.legifrance.gouv.fr/eli/decret/2017/9/29/ECOC1716648D/jo/texte

Directive 2002/77/EC of the Commission of 16 September 2002 on competition in the markets for electronic communications, networks and services [2002] OJ L249/21. Available at http://data.europa.eu/eli/dir/2002/77/oj 
Dredge, S. (2013, October 22). ERA Says Apple’s HMV App Ban Raises “Serious Issues Of Competition". Musically. Retrieved from

http://musically.com/2013/10/22/era-says-apples-hmv-app-ban-raises-serious-issues-of-comp etition/

Easterbrook, F. (1996). Cyberspace and the Law of the Horse. University of Chicago Legal Forum, 1996(1), 207-216. Available at https://chicagounbound.uchicago.edu/uclf/vol1996/iss1/7

Evans, D. (2017). Why the dynamics of competition for online platforms leads to sleepless nights but not sleepy monopolies. Retrieved from

https://papers.ssrn.com/sol3/papers.cfm?abstract_id=3009438 doi:10.2139/ssrn.3009438

European Commission (2009). Guidance on enforcement priorities in applying Article 82 of the EC Treaty to abusive exclusionary conduct by dominant undertakings [2009] OJ C45/7. Available at https://eur-lex.europa.eu/legal-content/EN/ALL/?uri=CELEX:52009XCo224(O1)

European Commission (2013, April 25). Commission seeks feedback on commitments offered by Google to address competition concerns. Press release. Available at

http://europa.eu/rapid/press-release_IP-13-371_en.htm

European Commission (2016a). Online platforms and the Digital Single Market: opportunities and challenges for Europe. Communication, $\operatorname{COM}(2016) 288$. Available at http://eur-lex.europa.eu/legal-content/EN/TXT/?uri=CELEX:52016DCo288

European Commission (2016b). Public consultation on the regulatory environment for platforms, online intermediaries and the collaborative economy. Synopsis Report. Available at https://ec.europa.eu/digital-single-market/en/news/results-public-consultation-regulatoryenvironment-platforms-online-intermediaries-data-and

European Commission (2017a, June 27). Commission fines Google $€ 2.42$ billion for abusing dominance as search engine by giving illegal advantage to own comparison shopping service. Press release, IP/17/1784. Available at http://europa.eu/rapid/press-release_IP-17-1784_en.htm

European Commission (2017b, June 27). Commission fines Google $€ 2.42$ billion for abusing dominance as search engine by giving illegal advantage to own comparison shopping service. Fact sheet, MEMO/17/1785. Available at

http://europa.eu/rapid/press-release_MEMO-17-1785_en.htm

European Commission (2017c). Mid-Term Review on the implementation of the Digital Single Market Strategy. Communication, $\operatorname{COM}(2017)$ 228. Available at

http://ec.europa.eu/newsroom/document.cfm?doc_id=44527

European Commission (2017d). Fairness in platform-to-business relations. Inception impact assessment, Ref. Ares(2017)5222469. Available at https://ec.europa.eu/info/law/betterregulation/initiatives/ares-2017-5222469_en

European Council (2017, October 19). Conclusions meeting, Brussels, EUCO 14/17. Available at http://data.consilium.europa.eu/doc/document/ST-14-2017-INIT/en/pdf

European Parliament (2014). Supporting consumer rights in the digital single market. 
Resolution, 2014/2973(RSP). Available at

http://www.europarl.europa.eu/sides/getDoc.do?pubRef=-//EP//TEXT+TA+P8-TA-2014-007 $1+\mathrm{O}+\mathrm{DOC}+\mathrm{XML}+\mathrm{Vo} / / \mathrm{EN}$

European Parliament (2017). Online platforms and the digital single market. Report, A8-

0204/2017. Available at

http://www.europarl.europa.eu/sides/getDoc.do?type=REPORT\&reference=A8-2017-0204\&fo rmat $=$ XML\&language $=\mathrm{EN}$

Ezrachi, A. \& Stucke, M. (2016). Virtual competition: the promise and perils of the algorithmdriven economy. Cambridge, Massachusetts: Harvard University Press.

Foundem et al. (2018, February 2018). Letter to Commissioner Vestager re: AT.39740 - Google Search (Comparison Shopping). Retrieved from

http://www.foundem.co.uk/Open_Letter_Commissioner_Vestager_Feb_2018.pdf

Franken, A. (2017, November 8). We must not let big tech threaten our security, freedoms and democracy. The Guardian. Retrieved from

https://www.theguardian.com/commentisfree/2017/nov/o8/big-tech-security-freedoms-demo cracy-al-franken

German Monopolies Commission (2015). Competition policy: The challenge of digital markets. Special Report, No 68. Available at

http://www.monopolkommission.de/images/PDF/SG/s68_fulltext_eng.pdf

Google Search (Shopping) (2017). Case AT.39740. Decision of the European Commission of 27 June 2017. Available at

http://ec.europa.eu/competition/antitrust/cases/dec_docs/39740/39740_14996_3.pdf

Google India (2017). Case Nos. 07 and 30 of 2012. Decision of the Competition Commission of India of 8 February 2018. Available at

http://www.cci.gov.in/sites/default/files/o7\%20\%26\%20\%2030\%20of\%202012.pdf

Heckmann, O. (2017, September 27). Changes to Google Shopping in Europe. Google Inside AdWords blog. Retrieved from https://adwords.googleblog.com/2017/o9/changes-to-googleshopping-in-europe.html

Joint letter (2016, April 4). from the governments of eleven member states to Commission VicePresident Andrus Ansip. Retrieved from

https://www.gov.uk/government/uploads/system/uploads/attachment_data/file/513402/platf orms-letter.pdf

Kadar, M. (2015). European Union competition law in the digital era. Zeitschrift für Wettbewerbsrecht, 13(4), 342-363. doi:10.15375/zwer-2015-0403 Retrieved from https://papers.ssrn.com/sol3/papers.cfm?abstract_id=2703062

Khan, L. (2017). Amazon's Antitrust Paradox. Yale Law Journal, 126(3), 710-805. Available at https://www.yalelawjournal.org/note/amazons-antitrust-paradox

Lamadrid, A. (2015, November 24). Regulating platforms? A competition law perspective. Chillin' Competition. Retrieved from https://chillingcompetition.com/2015/11/24/regulatingplatforms-a-competition-law-perspective/ 
Lobel, O. (2016). The Law of the Platform. Minnesota Law Review, 101, 87-166. Available at http://www.minnesotalawreview.org/wp-content/uploads/2016/11/Lobel.pdf

Loi $\mathrm{n}^{\circ}$ 2016-1321 du 7 octobre 2016 pour une République numérique.

Luca, M. et al. (2016). Does Google Content Degrade Google Search? Experimental Evidence. Harvard Business School Working Paper, 16-035, 44p. Retrieved from http://people.hbs.edu/mluca/SearchDegradation.pdf

Martens, B. (2016). An Economic Policy Perspective on Online Platforms (Digital Economy Working Paper No. 2016/o5). Joint Research Center of the European Commission, Institute for Prospective Technological Studies. Retrieved from https://ec.europa.eu/jrc/sites/jrcsh/files/JRC101501.pdf

Maxwell, W. \& Pénard, T. (2015). Regulating digital platforms in Europe - a white paper. Retrieved from https://papers.ssrn.com/sol3/papers.cfm?abstract_id=2584873

OECD (2011). Principles for Internet Policy Making. Council Recommendation.

Open Internet Order (2015). Federal Communications Commission, Report and Order on Remand, Declaratory Ruling, and Order in the Matter of Protecting and Promoting the Open Internet, adopted 26 February 2015.

French Senate, Projet de loi Croissance, activité et égalité des chances économiques, Article additionnel après article 33 nonies (supprimé). Retrieved from www.senat.fr/amendements/2014-2015/371/Amdt_995.html

Rato, M. \& Petit, N. (2014). Abuse of Dominance in Technology-Enabled Markets: Established Standards Reconsidered. European Competition Journal, 9(1), 1-65.

doi:10.5235/17441056.9.1.1

Regulation (EU) 2015/2120 of the European Parliament and of the Council of 25 November 2015 laying down measures concerning open internet access [2015] OJ L310/1. Available at https://eur-lex.europa.eu/legal-content/EN/TXT/?uri=CELEX:32015R2120

Renda, A. (2015). Antitrust, Regulation, and the Neutrality Trap: A plea for a smart, evidencebased internet policy (Special Report No. 104). Brussels: Centre for European Policy Studies. Retrieved from https://www.ceps.eu/system/files/SR104_AR_NetNeutrality.pdf

Rochet, J.-C. \& Tirole, J. (2003). Platform competition in two-sided markets. Journal of the European Economic Association, 1(4), 990-1029. doi:10.1162/154247603322493212

Shelanski, H. (2013). Information, innovation, and competition policy for the internet. University of Pennsylvania Law Review, 161(6), 1663-1705. Available at http://www.jstor.org/stable/23527815

Strowel, A. \& Vergote, W. (2016). Digital Platforms: To Regulate or Not to Regulate? Retrieved from

http://ec.europa.eu/information_society/newsroom/image/document/2016-7/uclouvain_et_u niversit_saint_louis_14044.pdf

Warren, E. (2016, June 29). Reigniting Competition in the American Economy. Keynote speech presented at the New America's Open Markets Program Event, Washington, D.C. Retrieved 
from https://www.warren.senate.gov/newsroom/press-releases/senator-elizabeth-warrendelivers-remarks-on-reigniting-competition-in-the-american-economy

Wen, W., \& Zhu, F. (2017). Threat of Platform-Owner Entry and Complementor Responses: Evidence from the Mobile App Market (Working Paper No. 18-036). Harvard Business School. Retrieved from https://www.hbs.edu/faculty/Pages/item.aspx?num=53422

Wu, T. (2003). Network Neutrality, Broadband Discrimination. Journal on Telecommunications and High Technology Law, 2, 141-179.

Zhu, F., \& Liu, Q. (2016). Competing with Complementors: An Empirical Look at Amazon.com (Working Paper No. 15-044). Harvard Business School. Retrieved from https://www.hbs.edu/faculty/Pages/item.aspx?num=48334

\section{FOOTNOTES}

1. The 30\% fee has long been the industry standard (although the Google Play Store allows for certain exceptions). It applies to every in-app media purchase, so not to the purchase of services provided 'outside' of the app, e.g. an Uber ride or an Airbnb stay. Apple recently lowered its cut to $15 \%$ for long-term in-app subscriptions (i.e. when the customer has been subscribed for over a year), and Google quickly followed suit. 